\title{
Czestaw Zajac
}

\section{ŹRÓDŁA POWSTAWANIA WIĘZI PERSONALNYCH W GRUPACH KAPITAŁOWYCH JAKO WAŻNEGO ELEMENTU KAPITAŁU SPOŁECZNEGO}

Zarys treści. W artykule zaprezentowano więzi personalne w grupach kapitałowych. Zgodnie z przyjętym celem opracowania dokonano analizy najważniejszych źródeł powstawania tego rodzaju więzi. Źródła te obejmują: naśladownictwo, zaufanie oraz współdziałanie wewnątrz-organizacyjne. Analiza objęte zostały mechanizmy tworzenia więzi personalnych w zgrupowaniach przedsiębiorstw, prezentowane w kontekście różnych podejść do imitacji (naśladownictwa), zaufania oraz współdziałania wewnątrz-organizacyjnego oraz modeli opisujących te kategorie i procesy. W analizie tej szczególne znaczenie merytoryczne i metodologiczne ma koncepcja kapitału społecznego. Podstawę epistemologiczną prowadzonej analizy stanowią studia literatury przedmiotu przeprowadzone przez autora opracowania.

S łow a kluc z ow e : grupa kapitałowa, więzi personalne, naśladownictwo, zaufanie, współdziałanie wewnątrz-organizacyjne, kapitał społeczny.

\section{WPROWADZENIE}

Pojęcie kapitału społecznego zostało wprowadzone do nauk społecznych przez znanego socjologa i politologa amerykańskiego R.D. Putnama (Putnam 2008). W zamyśle autora miało być ono odzwierciedleniem obserwowanych w praktyce zjawisk ograniczania kontaktów społecznych, słabnięcia współpracy między jednostkami i grupami społecznymi, spadku liczby stowarzyszeń, upadku różnego rodzaju wspólnot i ducha kooperacji. Putnam dokonał rozróżnienia między tzw. „kapitałem integracyjnym” " ' kapitałem pomostowym”. O ile pierwszy rodzaj kapitału społecznego jest kapitałem spajającym, a zatem ekskluzywnym, o tyle drugi, inkluzywny, tworzy więzi pomiędzy różnymi grupami i ich 
członkami. Przykładem takich więzi mogą być więzi personalne występujące pomiędzy podmiotami grupy kapitałowej. Ich powstawanie może być postrzegane jako wynik wpływu różnorodnych uwarunkowań kształtujących procesy tworzenia tych więzi lub też, niezależnie od zamiarów decydentów, tworzących zgrupowanie przedsiębiorstw, jako ich wyłanianie się (emergencja) z procesów społecznych, zachodzących w układzie organizacyjnym grupy. Więzi personalne są przykładem więzi międzyorganizacyjnych. Istotę więzi międzyorganizacyjnych, należy rozpatrywać w określonych przedziałach czasu, danych warunkach otoczenia, poprzez pryzmat triady trzech, charakteryzujących je cech, tj. wymiany, zaangażowania oraz wzajemności. Więzi organizacyjne są skutkiem naśladownictwa (imitacji, mimetyzmu), zaufania oraz współdziałania organizacyjnego (Czakon 2007, s. 151).

Celem opracowania jest analiza każdego z wymienionych wyżej czynników, traktowanych jako źródła tworzenia więzi personalnych w grupach kapitałowych. Podstawę epistemologiczną do jego przygotowania stanowią studia literatury przedmiotu, przeprowadzone przez jego autora.

\section{NAŚLADOWNICTWO}

Naśladownictwo jako czynnik wyłaniania się więzi personalnych w grupach kapitałowych, opiera się zasadniczo na dwóch rodzajach procesów imitacji tj. procesie instytucjonalnym oraz procesie przymusowym, a w mniejszym stopniu na procesie konkurencyjnym. Proces konkurencyjny jako jeden z trzech opisywanych w literaturze przedmiotu procesów imitacji, odgrywa zdaniem autora opracowania, znacznie mniejszą rolę w powstawaniu więzi personalnych w grupach kapitałowych. Może on być brany pod uwagę jako czynnik wpływający na tworzenie się tego rodzaju więzi w sytuacjach, w których mamy do czynienia z grupami kapitałowymi typu międzynarodowe joint ventures czy alianse strategiczne, w których zachowania partnerów postrzegane są jako konkurowanie.

Wymienione wyżej procesy imitacji prowadzą do izomorfizmów, czyli ukształtowania się wśród podmiotów zgrupowania podobnych form relacji oraz zależności w jego przestrzeni społecznej.

Izomorfizm instytucjonalny polega na rozprzestrzenianiu się wśród uczestników zgrupowania praktyk zarządzania, standardów pracy, postaw i wartości, których generatorem jest wiodący, w sensie formalnego statusu lub poziomu profesjonalizacji zarządzania, podmiot tego zgrupowania. Prowadzi on do standaryzacji zachowań menedżerów i pracowników przedsiębiorstw tworzących grupę kapitałową oraz do ujednolicenia działań w obszarze operacyjnego zarządzania tymi przedsiębiorstwami. Egzemplifikacją izomorfizmu instytucjonalnego są procesy przejęć i fuzji przedsiębiorstw, w szczególności te o charakterze 
międzynarodowym. W procesach tych często benchmarkami są systemy operacyjne zarządzania oraz wzorce kulturowe, funkcjonujące w korporacji nowego właściciela (przedsiębiorstwo przejmujące) lub we wiodącym przedsiębiorstwie w ramach fuzji, a nośnikami nowoczesnych standardów są ekspatrianci (ekspaci). Pojęciem tym określanie są przedstawiciele nowego właściciela (spółka matka), delegowani do pracy w radach nadzorczych i zarządach podmiotów przejętych, zlokalizowanych za granicą, w celu kontrolowania i reprezentowania jego interesów (Child, Faulkner, Pitkethly 2000, s. 34; Cartwright, Cooper 1998; Zając 2006, s. 134-136). Silny wpływ na przebieg takiego naśladownictwa, jego charakter i zasięg ma kontekst kulturowy przejęcia lub fuzji, traktowanych w niniejszych rozważaniach jako sposób tworzenia grup kapitałowych (Olie 1990, s. 206-315).

Izomorfizmowi instytucjonalnemu w ramach grup kapitałowych towarzyszy izomorfizm ,przymusowy”, będący skutkiem imitacji zachowań decydentów reprezentujących podmiot dominujący przez menedżerów z podmiotów podporządkowanych. Takiemu naśladownictwu sprzyja obecność przedstawicieli spółki dominującej w radach nadzorczych lub zarządach tych spółek oraz aktywne ich uczestnictwo w pracach tych organów, czyli unia personalna, która prowadzi, do powstawania więzi personalnych wewnątrz grupy kapitałowej. Jeśli te osoby posiadają rozwinięte kompetencje menedżerskie, a w swojej pracy kierują się zasadami etyki zawodowej i biznesowej, to takie rozwiązanie organizacyjne należy uznać za korzystne. Sprzyja ono bowiem profesjonalizacji zarządzania w całej grupie kapitałowej oraz upowszechnianiu się pożądanych wartości i norm kulturowych, przyczyniając się w ten sposób do wzmocnienia jej potencjału konkurencyjnego. Prowadzi także do izomorfizmu konkurencyjnego, czyli rozprzestrzeniania się najlepszych praktyk zarządzania, standardów pracy oraz wartości i norm, kształtujących racjonalne i korzystne z punktu widzenia całej grupy kapitałowej, zachowania i postawy menedżerów oraz pracowników zatrudnionych w przedsiębiorstwach tworzących tę grupę. Sprzyja również organizacyjnemu uczeniu się przez te podmioty od lidera w zakresie praktyk zarządzania, jakim jest w tym przypadku przedsiębiorstwo prowadzone przez spółkę nadrzędną.

\section{ZAUFANIE}

Zaufanie, obok transparentności (przejrzystości) jest uznawane coraz powszechniej za cenną wartość. Jej brak lub niedostatek odczuwa wiele organizacji, co potwierdzają badania empiryczne dotyczące relacji biznesowych (Podolny 2009). Zaufanie jako element budowania relacji wewnątrz-organizacyjnych, w naukach o zarządzaniu interpretowane jest jako wzajemne przekonanie, ze żadna ze stron nie wykorzysta słabości drugiej strony przeciwko niej (Sabel 1993, s. 1133). Postrzegane jest ono jako kategoria wielowymiarowa, w wymiarze 
osobowościowym, kalkulacyjnym, instytucjonalnym, percepcyjnym oraz kumulacyjnym. Szersze wejrzenie w głąb każdego z wymienionych wymiarów, w granicach wyznaczonych przez wewnętrzną strukturę organizacyjną grupy kapitałowej, pozwala traktować je jako czynnik, który wywiera istotny wpływ na powstawanie wewnątrz niej więzi personalnych oraz charakter tego rodzaju więzi.

Wymiar osobowościowy zaufania w układzie organizacyjnym grupy kapitałowej wyznaczają czynniki kulturowe, przede wszystkim wartości, normy oraz przekonania podzielane przez wszystkich lub co najmniej większość pracowników i menedżerów przedsiębiorstw tworzących tę grupę. Wymiar ten związany jest zatem z podmiotowym charakterem kategorii zaufania. Wymienione czynniki kulturowe tworzą także fundament do budowania zaufania między-organizacyjnego. Zaufanie pojmowane jako wypadkowa zaufania między ludźmi oraz zaufania między organizacjami stanowi zatem dodatkowy, poza naśladownictwem, czynnik silnie wspierający wykorzystywanie przez podmioty podporządkowane wiarygodnych procedur, praktyk zarządzania, rozwiązań strukturalnych i operacyjnych, stosowanych w przedsiębiorstwie prowadzonym przez spółkę nadrzędną. Ważną rolę w budowaniu owej wiarygodności odgrywają fachowość oraz zachowania i postawy menedżerów - uczestników unii personalnej.

Wymiar kalkulacyjny zaufania bazuje na kalkulacji (szacowania) korzyści i kosztów budowania relacji zaufania dokonywanej przez jednostki - uczestników organizacji. Ten wymiar zaufania odniesiony do uczestników grupy kapitałowej prowadzi do wniosku, że na etapie podejmowana decyzji o tworzeniu zgrupowania przedsiębiorstw, decydenci uznają, że bardziej opłacalne jest osiąganie korzyści kosztem wzajemnej współpracy (współdziałania), niż uzyskiwanie korzyści na drodze rywalizacji. Kalkulacja korzyści i kosztów, o których mowa, winna dotyczyć wszystkich partnerów - uczestników grupy kapitałowej. Użyteczne metodyczne podstawy dla takiej kalkulacji tworzy teoria gier. Zastosowanie dwóch kluczowych elementów tej teorii tj. schematu wypłat, pojmowanego jako uporządkowane, ilościowe odzwierciedlenie korzyści wynikających z postawy kooperacyjnej lub oportunistycznej oraz preferencji decydenta, ujmowanych jako kolejność wariantów decyzji, uzyskaną ze względu na kryterium jego maksymalnej korzyści, pozwala na identyfikację zachowań wszystkich graczy podmiotów tworzących grupę (Malawski, Wieczorek, Sosnowska 2004, s. 30). Umożliwia również wskazanie warunków, w których racjonalnie zachowujący się menedżerowie przedsiębiorstw - podmiotów zgrupowania, będą orientowali się na współpracę. Do tych warunków należy zaliczyć takie kształtowanie struktury (schematu) wypłat, które gwarantuje przewagę korzyści wynikających ze współpracy nad alternatywnie rozpatrywanymi korzyściami z potencjalnej rywalizacji oraz zapewnienie wielokrotności (powtarzalności) gry (Czakon, Borczuch 2005, 
s. 18-21). Spełnienie tego drugiego warunku, gwarantuje długotrwały charakter grupy kapitałowej. Zgodnie z teorią gier, zakres wzajemnego zaufania wśród uczestników grupy kapitałowej wyznaczają także: troska każdego z nich o własną reputację, zachowanie symetrii zachowań oraz możliwość sankcjonowania zachowań sprzecznych ze wspólnymi celami grupy kapitałowej. Zatem przewidywanie przyszłych zachowań partnerów bazuje na szacowanym (kalkulowanym) zakresie udzielania sobie wzajemnego zaufania. Podstawą do udzielania takiego zaufania może stanowić reputacja partnerów. Dobra (pozytywna) reputacja, rozpatrywana jako źródło zaufania, traktowana jest przez niektórych autorów jako warunek powstawania (wyłaniania się) więzi międzyorganizacyjnych (Ariano, De la Torre, Ring 2001, s. 110). Zgodnie z poglądami prezentowanymi w literaturze przedmiotu, pozytywną reputację w rozpatrywanym kontekście należy pojmować zarówno jako informację o faktycznym wypełnianiu zobowiązań zaciąganych w przeszłości przez partnerów (Dolinger, Golden, Santon 1997, s. 127), cenny zasób przedsiębiorstwa, umożliwiający mu konkurowanie (Barney, Hansen 1994, s. 17-190), jak też krytyczny czynnik jego sukcesu (Blomqvist, Stahle 2004). Możliwość wzajemnego przewidywania zachowań uczestników grupy kapitałowej oraz możliwość interpretowania ich celów, które są zdeterminowane statusem poszczególnych podmiotów w grupie oraz charakterem występujących między nimi więzi kapitałowych oraz pozostałych, poza personalnymi, więzi uzupełniających, wyznaczają instytucjonalny wymiar zaufania. Budowaniu zaufania w tym wymiarze sprzyja również przejrzystość (transparentność) układu organizacyjno-strukturalnego grupy kapitałowej oraz ład organizacyjny wyznaczony przez jej architekturę.

Rozwiązaniem modelowym „kompatybilnym” z architekturą grupy kapitałowej oraz odpowiadającym ,naturze" jej wewnętrznych powiązań jest model zaufania interorganizacyjnego J. Sydowa, który obejmuje sześć właściwości dotyczących współpracujących organizacji - uczestników sieci oraz relacji pomiędzy tymi organizacjami: częstość i otwartość komunikacji, multiplikatywność relacji sieciowych, otwartą kolekcję relacji, równowagę relacji pomiędzy autonomią i zależnością (podporządkowaniem), liczbę i jednolitość organizacji w sieci oraz strukturę inter - organizacyjnego obszaru (Sydow 2000, s. 38-42).

Wzajemne postrzeganie siebie jako partnerów współdziałających na rzecz realizacji celów grupy kapitałowej jako całości oraz działających we własnym interesie, wspólne wartości i normy kulturowe, tworzą wymiar percepcyjny zaufania, a wiedza na temat partnerów jaką dysponują podmioty tworzące grupę, połączona $\mathrm{z}$ ich zdolnością do wypełniania własnych zobowiązań, stanowi jego wymiar kumulacyjny. Zaufanie rozpatrywane w tych dwóch ostatnich wymiarach stanowi ważny czynnik integracji wewnętrznej oraz element silnego poczucia tożsamości z grupą kapitałową przez jej uczestników (Kordel 2002, s. 83-88). 


\section{WSPÓŁDZIAŁANIE WEWNĄTRZ-ORGANIZACYJNE}

Współdziałanie wewnątrz-organizacyjne, stanowi trzecie ważne źródło wyłaniania się $\mathrm{w}$ ich strukturach więzi personalnych. W literaturze przedmiotu podkreślane jest znaczenie powtarzalności bilateralnych i multilateralnych transakcji pomiędzy przedsiębiorstwami dla wzbogacania relacji pomiędzy nimi o zaangażowanie wzajemne, wierność partnerom oraz przyzwyczajenie. Prowadzi ono do przekształcania tego rodzaju relacji w więzi międzyorganizacyjne (Czakon 2005, s. 429-437; Nooteboom, De Jong, Vossen, Helper, Sako 2000, s. 118).

Tym nie mniej zaangażowanie każdej ze spółek podporządkowanych w proces kooperacji w ramach grupy, zorientowane jest również na zaspakajanie własnych interesów organizacyjnych, osiąganych poprzez realizację celów grupy jako całości. Na straży interesów grupy stoi spółka dominująca. Zaangażowanie, to rozpatrywane na początku jako zaangażowanie jednostronne, prowadzi w konsekwencji do zaangażowania partnerów. Skutkiem takiego wzajemnego zaangażowania stron jest wyłonienie się pomiędzy nimi więzi międzyorganizacyjnych oraz budowa klimatu zaufania, otwartości i wzajemnej lojalności. Zwiększa to prawdopodobieństwo powtarzalności działań podmiotów podejmowanych w interesie całej grupy. Otwierają się również perspektywy dalszej ich współpracy. Tym samym tworzy się baza dla wyłaniania się więzi personalnych wewnątrz zgrupowania przedsiębiorstw, stanowiących istotny element spajający tkankę organizacyjną i społeczną tego zgrupowania. W takim „miękkim” podejściu do współdziałania podmiotów gospodarczych w ramach grupy kapitałowej, więzi personalne, traktowane jako jej element architektoniczny, są zatem skutkiem zachodzących wewnątrz niej określonych procesów społecznych i organizacyjnych. Procesy te obdarzone są cechami charakterystycznymi, dla omówionych wcześniej na gruncie teorii sieci, układów sieciowych przedsiębiorstw. Do najważniejszych spośród tych cech należą mimetyzm, oznaczający wzajemne „zarażanie" się uczestników zgrupowania, postrzegane także w kontekście ich uczenia się od kooperantów oraz „warunkowanie”, wynikające ze statusu konkretnego podmiotu, wyznaczającego jego zakres autonomii decyzyjnej, możliwości dokonywania wyborów oraz zakres i siłę wpływu na pozostałych uczestników grupy. „Warunkowanie” prowadzi również do ograniczania racjonalności decyzji i działań gospodarczych (biznesowych) każdego z podmiotów podporządkowanych. Pozytywnym skutkiem powstałych w ten sposób więzi personalnych jest wzrost wiarygodności uczestników współdziałania gospodarczego i organizacyjnego w ramach grupy kapitałowej oraz wzmocnienie wśród nich poczucia tożsamości i identyfikacji z grupą. 


\section{ZAKOŃCZENIE}

Problematyka powstawania więzi personalnych w grupach kapitałowych jest złożona. Dokonana przez autora opracowania syntetyczna analiza naśladownictwa, zaufania oraz współdziałania wewnątrz-organizacyjnego, które zostały potraktowane jako kluczowe źródła tworzenia tego rodzaju więzi, stanowi jedynie „teoretyczny” przyczynek do planowanych, bardziej dogłębnych badań empirycznych tego zagadnienia. Warto na zakończenie podkreślić wpływ unii personalnej na tworzenie się więzi personalnych w strukturach holdingowych, co zostało zasygnalizowane wcześniej w treści prowadzonych rozważań. Wpływ ten może być konstruktywny lub destrukcyjny z punktu widzenia charakteru oraz „jakości” powstających więzi personalnych, rozpatrywanych jako spoiwo całego układu architektonicznego grupy kapitałowej, postrzeganego w wymiarze organizacyjnym i społecznym. Zależy to przede wszystkim od takich czynników jak model zarządzania dana grupa kapitałową, wyznaczający jej układ organizacyjno strukturalny, a w nim relacje zachodzące między spółką nadrzędną i spółkami podporządkowanymi oraz model funkcjonowania rady nadzorczej grupy wyznaczający zakres i charakter występującego w niej nadzoru właścicielskiego. Jak się wydaje, dobrą i obiecującą perspektywą metodologiczną dla prowadzenia badań w tym zakresie może być koncepcja „kapitału społecznego” Putnama..

\section{LITERATURA}

Ariano A., De la Torre J., Ring P.S. (2001), Relational Quality: managing Trust In Corporate Alliances, „California Management Review”, Vol. 44, No 1.

Barney J.B., Hansen M.H. (1994), Trustworthiness as a source of Competitive Advantage, „Strategic Management Journal”, Vol. 15, Special Issue.

Blomqvist K., Stahle P. (2004), Trust in technology partnership, [w:] (red.) M.L. Huotari, I. Iivonen, Trust in knowledge management and systems in organizations, Idea Group Publishing, Hershey.

Czakon W., Borczuch A. (2005), Trwałość sieci gospodarczych w świetle teorii gier, „Przegląd Organizacji” nr 3.

Czakon W. (2005), Więzi konkurencyjne a więzi sieciowe przedsiębiorstwa, [w:] J. Pyka (red.), Nowoczesność przemystu i ustug. Wspótczesne koncepcje i metody zarzadzania przedsiębiorstwami, TNOiK Katowice.

Czakon W. (2007), Dynamika więzi międzyorganizacyjnych przedsiębiorstwa, Wydawnictwo Akademii Ekonomicznej im. Karola Adamieckiego w Katowicach, Katowice. 
Cartwright S., Cooper C.L.,, Jordan J. (1998), Managerial Preferences In International Merger and Acquisition Partner, [w:] W.D. Hussey (red.), The Strategic Decision Challenge, John Wiley \& Sons, Chichester.

Child J., Faulkner D., Pitkethly R. (2001), The Management of International Acquisitions, Oxford University Press, New York.

Dolinger M.J., Golden P. A., Santon T. (1997), The Effect of Reputation on the Decision to Joint Venture, „Strategic Management Journal”, Vol. 18, No 2.

Kordel P. (2002), Zaufanie a proces tworzenia strategii przedsiębiorstw, „Organizacja i Kierowanie", nr 2 (108).

Malawski M., Wieczorek A., Sosnowska H., (2004), Konkurencja i kooperacja. Teoria gier w ekonomii i naukach społecznych, PWN, Warszawa.

Nooteboom B., De Jong G., Vossen R., Helper S., Sako M. (2000), Networks Interactions and Mutual Dependence: a Test in the Car Industry, „Industry and Innovation”, Vol. 7, No 1.

R.Olie, Culture and Integration Problems In International Mergers and Acquisitions, „European Management Journal” 1990, nr 8 (2).

Podolny J.M., (2009), The Buck Stops and Starts at Business School, „Harvard Business Review", No 87 (6).

Putnam R.D., Samotna gra w kręgle. Upadek i odrodzenie wspólnot lokalnych w Stanach Zjednoczonych, Warszawa 2008

Sabel Ch. (1993), Studied Trust: Building New Forms of Cooperation in a Volatile Economy, „Human Relations”, Vol. 4 No 9.

Sydow J. (2000), Understanding the Constitution of Interorganizational Trust, [w:] Trust within and between organizations, (red.) C. Lane, R. Bachmann, Conceptual Issues and Empirical Applications, Oxford University Press, Oxford.

Zając Cz. (2006), Społeczne i organizacyjne problemy przejęć i fuzji przedsiębiorstw, Wydawnictwo Akademii Ekonomicznej im. Oskara Langego we Wrocławiu, Wrocław.

\section{SOURCES OF CREATING OF PERSONAL TIES IN CAPITAL GROUPS (HOLDINGS)}

A b s tract. The paper presents the creating of personal ties in capital groups (holdings). According to the aim of this article key sources of creating of such ties have been analyzed. These sources embrace: the imitation processes, confidence and internal organizational co-operation. Mechanisms of creating of personal ties in holdings have been portrayed in he context of different approaches and models describing these categories and processes mentioned above. The epistemological framework for the analysis are results of literature studies conducted by the author of this paper.

Key words: capital groups (holdings), personal ties, imitation, confidence, cooperation within organization 